\title{
The Legacy of Alois Riegl: Material Authenticity of the Monument in the Digital Age
}

\author{
Alexandra Harrer \\ School of Architecture, Tsinghua University, Beijing, China \\ Email: harrer@tsinghua.edu.cn
}

\begin{abstract}
The Austrian art historian Alois Riegl (1858-1905) revolutionised the European concept of the monument and paved the way towards the codification of the historicity of artefacts at the international level. Today, conservation work and relevant terminology still build upon the principles first outlined in his work Der moderne Denkmalkultus (1903) more than a hundred years ago. And yet, modern information/communication technologies have long challenged the idea of 'age value' (Alterswert), of a monument possessing value simply because it shows 'signs of age' (Altersspuren), through their ability to digitally recreate historical architecture in its original form and thereby to transcend the boundaries of time and space. This paper discusses the challenges and opportunities for monument preservation in the $21^{\text {st }}$ century in the light of Riegl's thoughts on how to perceive ('visualise') the past. It investigates the validity of Riegl's theories in the context of today's virtual reality/ies at a theoretical level, and their potential for advancement in preservation theory, expanding on historical thoughts rooted in $18^{\text {th }}$ and $19^{\text {th }}$ century preservation theories. By analysing Riegl's commemorative values, stratigraphic picturing of history's material debris, and fear of formlessness, this paper explores digitisation as the driving force for change in attitude from traditional, restrictive thinking to a modern way of thinking which is receptive to new technological developments, including, for example, exploring augmented and virtual realities as a means of achieving the sensory aesthetic experience required by age value.
\end{abstract}

KEYWORDS Alois Riegl, Austrian (Habsburg) Empire, modern conservation theory, material authenticity, age value (Alterswert), digital environment, virtual reality/ies, aesthetic experience, stratigraphic picturing, conjectural recovery

Received April 1, 2017; accepted May 31, 2017.

\section{Introduction}

'It is spick-and-span-new and ready for use (C'est flambant neuf, et prêt à servir).' (Zerner 1976, 186)

The famous line by the French art critic Louis Dimier (1865-1943) mockingly describes Eugène Viollet-le-Duc's (1755-1849) interpretive rational restoration of the medieval fortified town of Carcassonne, France, to its supposedly pristine state. Ironically, almost a century later, we find ourselves still facing the same old problem of awkward newness. Today, cutting-edge technologies produce almost-too-perfect virtual renderings/replicas of heritage architecture where computer-generated walls appear in bright colours as if they have just been painted (Figure 1). Their life-like effects are in sharp contrast to Alois Riegl's (1858-1905) concept of 'age value' (Alterswert), whereby a monument possesses value simply by showing traces of age on its physical substance. Riegl, whose thoughts on the historicity of artefacts established the basis for conservation work today, denounces what he terms 'newness value' (Neuheitswert) as age value's most fierce opponent because of the competitive opposing action of incompatibles: 'We seem to face a hopeless conflict here: on the one hand is an appreciation of the old for its own sake, a view that condemns any renovation of the "old on principle"; on the other hand there is an appreciation of the new for its own sake, a view that seeks to remove all traces of age as disturbing and displeasing.' (Riegl 1903, 181)

In this paper, I want to challenge the Eurocentric understanding of age value, first outlined in Der moderne Denkmalkultus (Riegl 1903)', and the necessity for future 



Figure 1 Newness value, digital reconstruction of the Old Summer Palace (Source: Digital Yuanmingyuan, THID 2016). Figure 2 Alois Riegl (1858-1905) (Public domain image).

monument preservation in the digital environment to adhere to Riegl's principles in an age where new information and communication technologies have long come to remove all traces of age and transcend the boundaries of time and space.

\section{The Austrian Art Historian Alois Riegl and His Contribution to Monument Preservation}

The Austrian art historian Alois Riegl is probably best known for his research on the history of the development of styles, the focus in his early career (Figure 2) (Zerner 1976; Wood 2000; Gubser 2005).

\section{Art History}

Although he initially studied law, Riegl later switched to history and philosophy. His studies at the University of Vienna (Austrian Institute of Historical Research [Institut für Österreichische Geschichtsforschung]) and his work as a member of staff in the Austrian Museum of Art and Industry (Österreichische Museum für Kunst und Industrie; today the Museum of Applied Arts [Museum für Angewandte Kunst]) from 1883 to 1897 , holding the position of curator of textiles from 1887 onwards, laid the foundation for his work. His groundbreaking methods in art history are codified in his work entitled Stilfragen: Grundlegungen $z u$ einer Geschichte der Ornamentik, a book on the history of ornament that demonstrates his interest in theory and his interdisciplinary view of art history (Riegl 1893).

Riegl, in the tradition of the positivism of $19^{\text {th }}$-century historiography, challenged the basic structures of art historical periodisation (ancient, medieval, Renaissance, Baroque, modern) and argued against the general belief of artistic supremacy of some periods (major periods such as classical antiquity, high Renaissance) and decline in style of other periods (minor periods such as late imperial Rome, early medieval) - for a progressive development of history to ever higher levels. To Riegl, both high and low art was the expression of the wished-for rather than of reality, and stemmed from the 'will to art' of a particular period and place (Kunstwollen; also rendered as 'artistic volition'), a complex and highly-disputed term that became the key element in his evolutionary theory of art. The evolutionary model was based on 'increasing subjectivity in art, rather than progress toward an artistic ideal' (Lamprakos 2014, 422). Riegl thus shifted the focus on the viewer and the subjectivity of history-art and architectural history as the history of perception. Riegl's understanding of the will's desire for the more spiritual, developing from a haptic experience of space toward an optical one, is telling and underpins his explanatory model on how to visualise the past in terms of monuments ${ }^{2}$.

\section{Monument Protection}

Riegl is also a key figure in art conservation and monument protection (Bacher 1995; Scarrocchia 1995; Arjones Fernández 2007; Falser 2010; Lamprakos 2014). At the age of 44 , he became interested in the field of monument preservation, only a few years before his death in 1905. As the first Conservator General (Generalkonservator) appointed to the Imperial and Royal Central Commission 


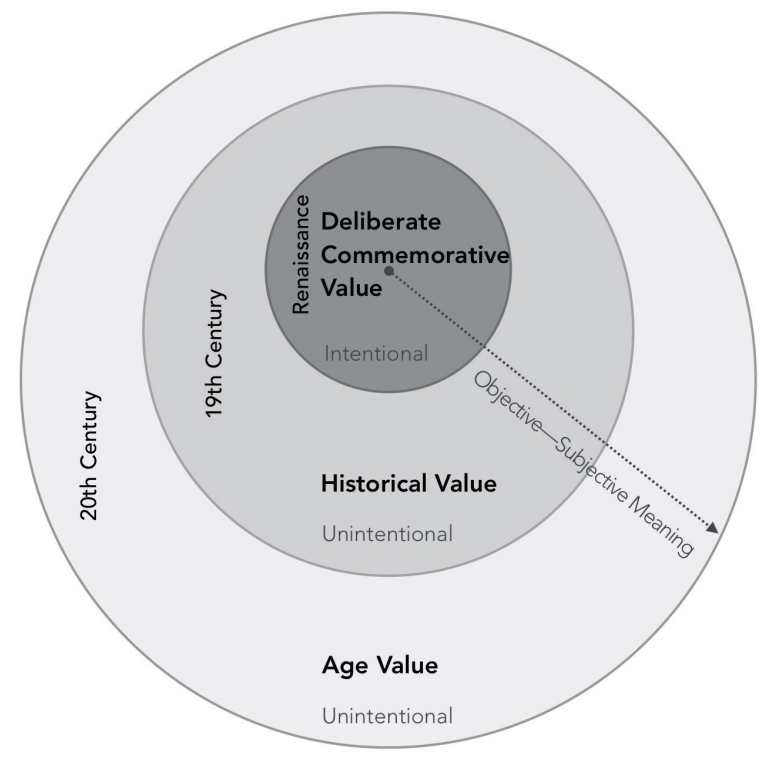

3

Figure 3 Evolution of Riegl's commemorative values (Source: the author).

for Researching and Preserving of Monuments (K.K. [Kaiserlich-Königliche] Zentral-Kommission für die Erforschung und Erhaltung der Baudenkmale)-a staterun advisory body without legislative means to enforce policy established in 1850-between 1903 and 1905, Riegl traveled throughout the Habsburg Empire, critically examining contemporary restoration practice, the favoured approach in the $19^{\text {th }}$ century, carried out according to the principles of 'stylistic unity' (Stileinheit; newness value) and later 'purity of style' or 'stylistic originality' (Stilreinheit; historic value) (Riegl 1903, 82). As a result, he decided to draft a monument protection law. His pioneering essay Der Moderne Denkmalkult is the preface and theoretical basis for the unfinished draft law, written only for a small expert audience.

The core of Riegl's theory of monument preservation is a system of values that describe the qualities for which a monument is valued. He identifies a set of past (memory or commemorative) values (Erinnerungswerte)-precisely deliberate commemorative value (gewollter Erinnerungswert), historical value (historischer Erinnerungswert), and age value (Alterswert) - and a set of present-day values (Gegenwartswerte)-namely use value (Gebrauchswert) and artistic value (Kunstwert), the latter further subdivided into newness value (Neuheitswert) and relative artistic value (relative Kunstwert; i.e. changing tastes). These values are 'not permanent categories but historical occurrences' (Zerner 1976, 186) - the Renaissance created the deliberate commemorative value, the $19^{\text {th }}$ century created the historical value, and the $20^{\text {th }}$ century created the age value. They correspond to the changing perception of the monument over time and represent consecutive stages of development from the objective to the subjective. Here, as with art history, increasing subjectivity (relativity) becomes the decisive factor and replaces traditional objective evaluation criteria. And yet, 'these stages do not [merely] succeed one another-rather they encompass one another' while 'the scope of their memory value widens' (Figure 3) (Lamprakos 2014, 423 and 425). That is to say, they [n]ever 'exist in purity; they always appear in conjunction and thereby in constant competition' (Lehne 2010, 79).

\section{Riegl's Three Commemorative Values in Detail}

Riegl developed his value system by distinguishing between intentional monuments (gewollte Denkmäler) built for a specific purpose and unintentional monuments (ungewollte Denkmäler) that are recognised only retrospectively by succeeding generations (after the maker generation). 'In case of deliberate monuments, the commemorative value is dictated to us by others (the former creators), while we define the value of unintentional monuments ourselves.' (Riegl 1903, 72)

\section{Deliberate Commemorative Value}

The deliberate commemorative value that characterises the intentional monument as bearer of collective memory 'makes a claim for immortality' that requires safeguarding and repair to maintain its commemorative function (Riegl 1903, 78) - for example, a stone stele can only record historic events or human deeds and keep them alive and present in the consciousness of future generations as long as the inscribed text is readable. In other words, for the small number of intentional monuments, the measure of restoration is acceptable and even necessary. But this then conflicts with age value:

In this category of monuments, the conflict with age value has naturally been constant. Without restoration monuments would soon cease to be deliberate; age value is, therefore, a sworn enemy of deliberate commemorative value. As long as mankind does not abandon the yearning for immortality, the cult of age value will find an insurmountable opponent in the cult of the deliberate commemorative value (Riegl 1903, 78).

\section{Historical Value}

The next value is the historical value. At the fin-de-siècle, monuments in Austria were officially called 'artistic and 


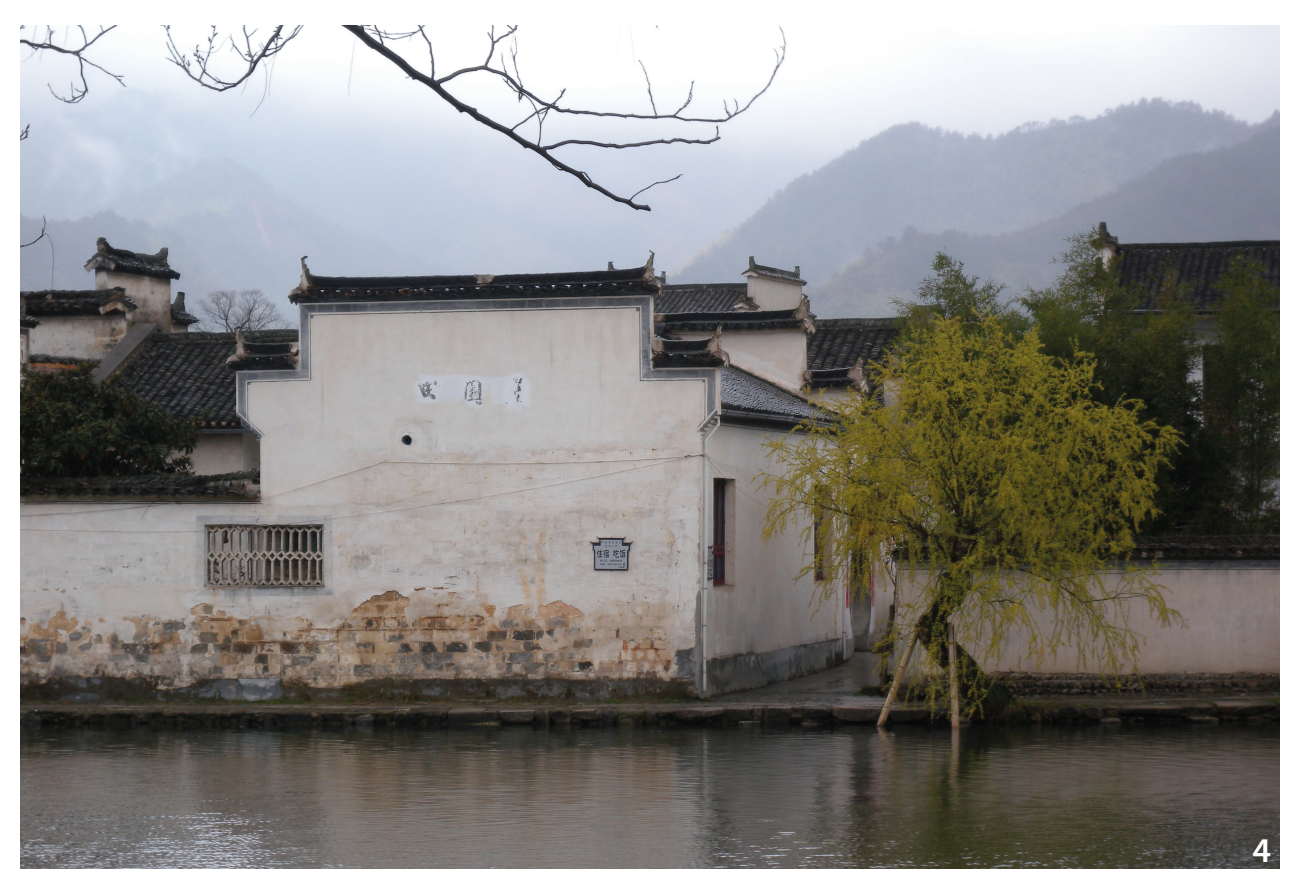

Figure 4 Age value, Residential houses in Hong village, Yixian district, Anhui province, China (Source: the author). historical monuments', a needless repetition in Riegl's view: 'Every monument of art is, without exception, a historical monument as well, since it represents a particular stage in the development of the fine arts for which no entirely equivalent replacement can be found.' (Riegl 1903, 69-70)

In other words, Riegl defined artistic monuments as (art-)historical monuments, the former being embraced by the latter, and valued them for their historical quality but not their artistic style. He degraded art value to the category of present-day value.

Riegl's concept of historical value must be seen in context: rooted in the politicised fin-de-siècle debates in the multinational Austro-Hungarian monarchy, it reflects the general shift away from stylistic restoration to materialcentered conservation (Olin 1985; Wood 2000). Historic buildings are perceived as documents of the past. Historical value thus relates to the monument's original form (physical substance; material) at a particular stage of development, and increases 'the more it remains uncorrupted and reveals its original state of creation; distortions and partial disintegrations are disturbing, unwelcome ingredients for historical value' (Riegl 1903, 75). The goal is to stop the progress of disintegration and preserve a monument in its present stage (form and material) for future generations in the most genuine form possible without restorative interventions to rebuild the past. Prior disintegration by the forces of nature cannot be undone and therefore should not be removed.

However, Riegl emphasises that 'further disintegration from the present day into the future is pointless and must be avoided, since any further disintegration hinders the scientific restoration' (Riegl 1903, 75). This then places the historical value in opposition to age value: 'Whereas age value is based solely on decay, historical value seeks to stop the progression of future decay, even though its entire existence rests on the decay that has occurred to the present day.' (Riegl 1903, 77)

\section{Age Value}

With this in mind, we can finally turn to age value, the most modern and important value according to Riegl and the one that applies and appeals to the largest number of monuments and people. In essence, every monument possesses age value without regard to its original significance, simply by growing older, i.e. showing marks of usage acquired with age such as imperfection, a lack of completeness, a tendency for shape and colour to dissolve (Figure 4). This approach rests on a simple rule-the biological life cycle-and results in the aesthetic principle of appearance according to age that is anchored in (the mindset of) a specific time and place-the fin-de-siècle and the central European Austro-Hungarian Empire. The underlying reasoning is as follows: monuments are perceived as natural organisms similar to man and should likewise live their lives freely, peacefully, and undisturbed (Riegl 1903, 73). Since man and monument are both subject to the laws of nature, they should abide by nature's law of the transition from growth to decay: i.e., where there is no human interference or measures have only been taken to prevent 


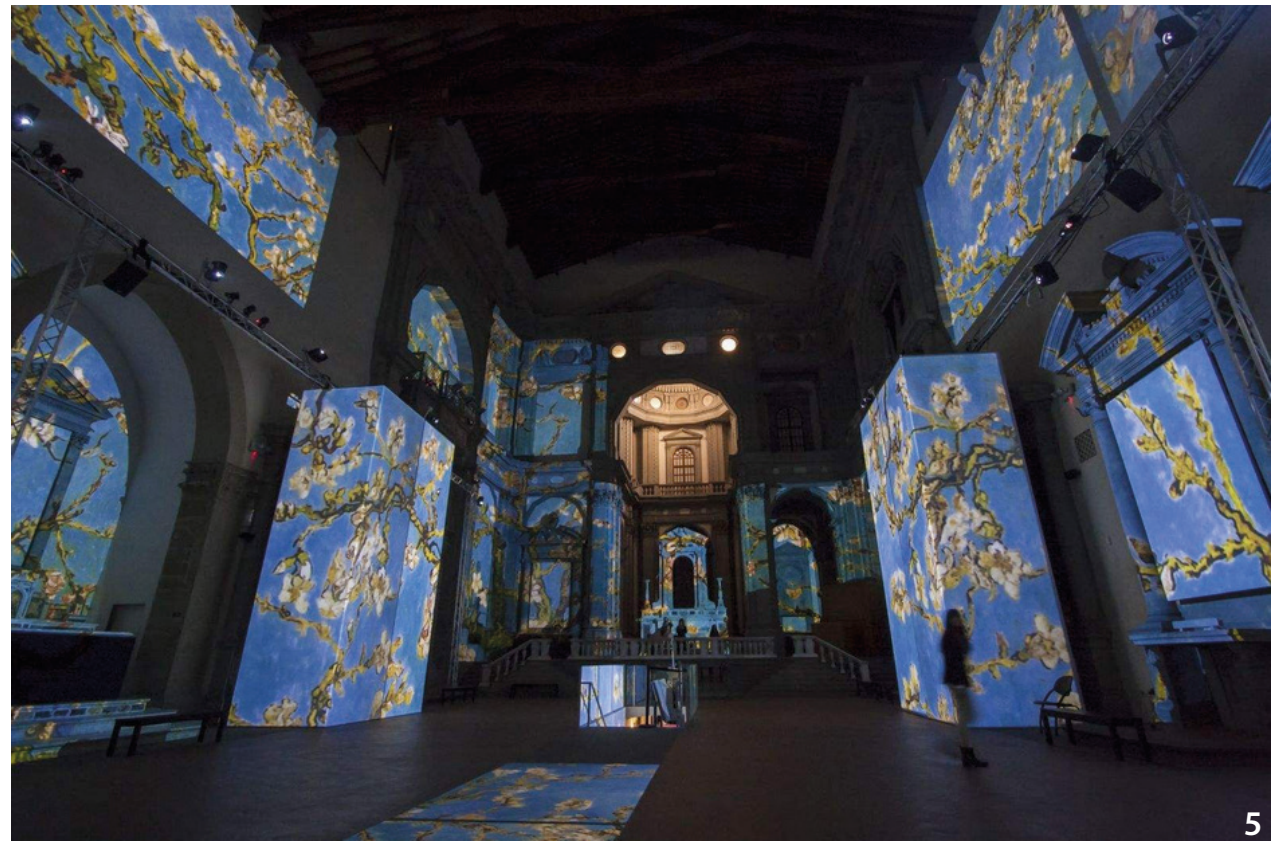

Figure 5 Emo-resonance reality (ER), Van Gogh Exhibition (Source: the author). premature demise, then we feel at ease when looking at the monument; otherwise, we might feel awkward, which results from the conflict between expectation ('it is old') and reality ('it looks new'), and vice versa: 'Signs of decay (premature aging) in new works disturb as much as signs of new production (conspicuous restoration) in old works.' (Riegl 1903, 73)

\section{Riegl's Historicity of Built Heritage in the Digital Age}

Next, after having clarified the scope and meaning of Riegl's commemorative values, I will reassess Riegl's age value and related ideas in the context of digital monument preservation and explore the potential for further growth inherent in $3 \mathrm{D}$ modelling and virtual rendering.

\section{Riegl's Age Value-Aesthetic Experience through Emotion}

Age value-for Riegl the highest stage in the perception (mental image) of the monument-rapidly achieved cult status on personal and national levels as part of a wave of nostalgia. It reflected the apocalyptic mood of the times in central Europe, particularly the Austro-Hungarian Empire that was increasingly shaken by ethnic conflicts and political crises (Olin 1985). The increased popularity can be explained by the basic assumption underlying age value that was as simple as it was enlightening: easy readability and accessibility without any previous knowledge made age value appealing to the masses, in contrast to the previously popular historical value that targeted only a small expert audience: 'Historical value rests on a scientific basis and therefore can only be achieved through intellectual reflection. Age value, to the contrary, addresses the viewer directly; it reveals itself through the most superficial sensory (visual) perception. To be sure, age value has the same scientific root as historical value, but age value will eventually signify the final scientific achievement for everyone; what the mind has honed will become accessible to the emotions.' (Riegl 1903, 74) As such, age value has (almost) a religious character, as Andreas Lehne observed: 'The age value addresses itself to the individual, to the mood of modern man (moderner Stimmungsmensch) directly and it promises him consolation, even redemption (Erlösung).' (Lehne 2010, 71)

In fact, it was Riegl himself who first drew an analogy to religion, not least because the cult of monument commemoration and veneration shares with religion the same concept of obedience in accepting the things we cannot change (Olin 1985): 'Age is based in a true Christian principle: that of humble acceptance of fate and the will of the Almighty.' (Riegl 1903, 70)

Human beings assume only an infinitely small place in the vast cosmos. Signs of aging, i.e., the natural organic process of growing older (from which nobody can escape), remind us of our impotence in the face of the forces of fate and nature and confront us with the cyclic impermanence of life ('the emergence of the particular from the whole and its gradual but necessary dissolution back into the whole') (Zerner 1976, 186). 
To Riegl, the (artificial) dilapidated ruins of a castle in the English landscape garden perfectly evoke this feeling of reverence for life and appreciation of the past (Riegl $1903,74)$. That is to say, the built environment, in whatever condition, is the stimulus that produces vivid experiences in the spectator. Assuming that all experience is perception, the viewer's emotional response becomes the decisive factor in understanding the monument. Age value addresses the emotions directly and thus provides an aesthetic experience of the monument realised through the viewer's sensory emotions; first and foremost, vision.

Such an aesthetic experience is not an objective rational decision-reality is perceived rather than rationalised through intellect-and depends on the individual viewer and the tastes of the time. Thus, it is subjective and subject to variation and change.

Today, 3D digital modelling and virtual reality certainly can stimulate feelings and facilitate communication with the public. They make information more accessible, more comprehensible, and more user-friendly. For almost two decades, virtual reality has provided an immersive, interactive experience generated by a computer that corresponds to the sensory aesthetic response required by Riegl. Furthermore, thanks to the pioneering concept of emo-resonance reality (ER), a new concept of interactive perception of reality that has been developed, the viewer can enter and sink into real-time images, thereby transcending the physical qualities of a monument for a spiritual encounter beyond the viewer's five senses or mind (Tsinghua Institute for Heritage Digitisation 2016) (Figure 5).

\section{Riegl's Stratigraphic Picturing of History's Mate- rial Debris-Materiality as Stimulus}

Similarly important, yet more complex, are Riegl's ideas on the stimulus (that triggers the aesthetic experience). The key here is the way of visualising the past, assuming that vision was the principal sense that processed the stimulus, as suggested by Riegl's emphasis on the optical qualities of a monument.

Naginski draws a convincing parallel between Riegl's mechanism of viewing and (fin-de-siècle) archaeological practices (Naginski 2001). They both make use of the historical gaze and stratigraphic picturing of history's material debris. Furthermore, they both control the perception process and thus are highly subjective. The practice of 'unearthing time so as to see its historical evolution' became standard in the field of archaeology at the turn of the $20^{\text {th }}$ century and is based on what is today known as Harris' laws of archaeological stratigraphy (e.g., the law of superposition, law of original continuity, law of stratigraphic succession) (Naginski 2001, 144; Harris 1993, 158). In very general terms, these laws advocate what Riegl captured in his compelling slogan: 'that what once was can never be again, and everything that once existed constitutes an irreplaceable and unremovable link in a chain of development' (Riegl 1903, 70).

As a result, monuments were redefined as 'degraded ruins' (characterised by degeneration of structure) and reduced to debris in the form of fallen stones or plaster (Naginski 2001, 136), which, by virtue of their (stratified) physical substance revealed the ageing processes that had created them. The passage of time that had elapsed is manifested once again, albeit in reverse order, in front of the viewer's eyes: directly and unadulterated. It is thus not surprising that Riegl advocates the preservation of these visible traces of age as the source of age value. His codification of the requirement for material authenticity is authenticity in terms of historic fabric, material and substance-physical remains are seen as evidence of a monument's creation and thus the visual manifestation of its right to exist.

This has an effect on an unimagined scale. Repercussions are being felt in modern preservation practice today, a practice which still builds on the International Charter for The Conservation and Restoration of Monuments and Sites (The Venice Charter 1964), which-already a 'historic document' itself-presents a one-sided, Europeanoriented view and (over)emphasis on materiality, i.e., historic substance and 'authentic material' (Petzet 2004). The point being made here is that for Riegl and succeeding generations of Western art historians and preservationists, monuments were defined and probably are still defined by material debris as a stimulus for the sensory aesthetic experience to value age. However, these tangible remains are required to walk a fine line between being 'grand enough in stature to suggest that it once was, and, at the same time, decayed enough to show that it no longer is', which is the prerequisite for the Western 'ideal ruin' as defined by Brodey (2008).

In 1994, the Nara Document on Authenticity elaborated the internationally-accepted standards for monument preservation codified in the Venice Charter, and, in a much-needed move to encompass cultural diversity, shifted the focus from a Eurocentric to a global definition of authenticity. This then immediately poses the question of how historical memory and the stimuli that trigger sensory perception are understood in the non-European 

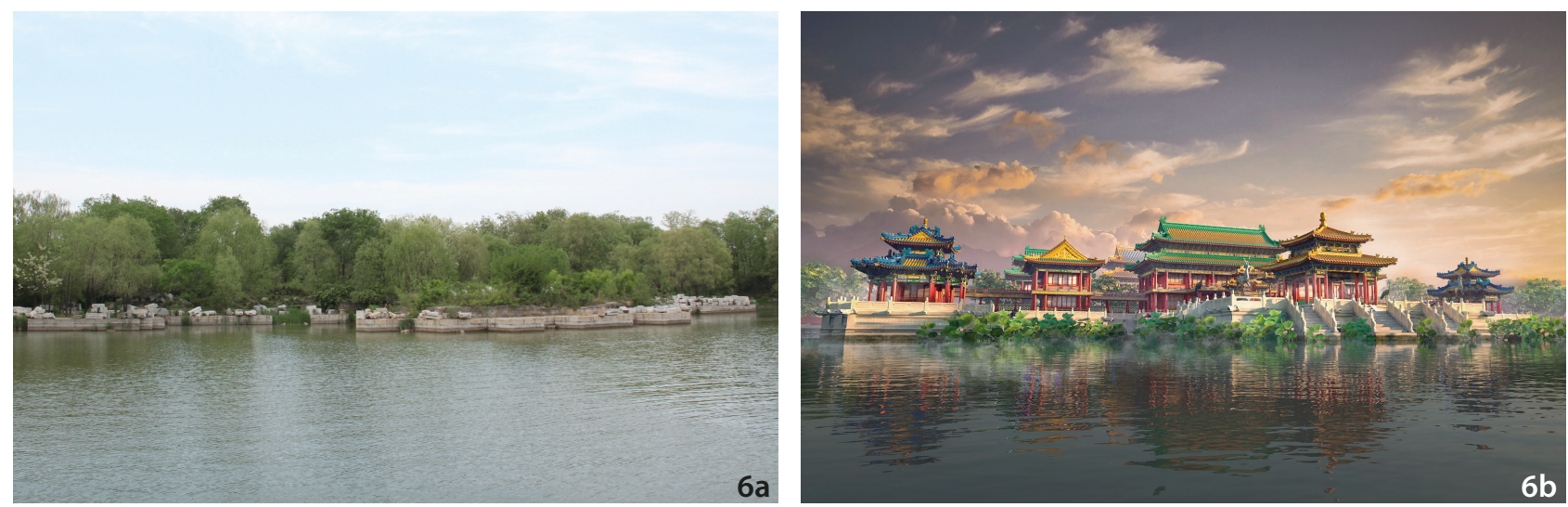

Figure 6a Virtual reality (VR), Fanghu shengjing scenic area in the Old Summer Palace, current site condition (Source: Digital Yuanmingyuan, THID 2016).

Figure $6 \mathrm{~b}$ Imaginary but realistic setting at the touch of a button (Source: Digital Yuanmingyuan, THID 2016).

context. For example, Wu Hong suggests that the concept of ruins (in the Western sense of 'fallen stones') could not develop in China, where the tectonic culture was firmly rooted in traditional wood craftsmanship and regular maintenance/repair of ephemeral timber-frame buildings (Wu 2012). The fact that less importance was put on material authenticity-due to the need for replacing torn or broken building components with new and intact ones to guarantee the overall stability of the monument-becomes evident in the lack of artistic representations: no paintings of degraded ruins exists that date from before the first encounters with Western culture in the $18^{\text {th }}$ century when European travelers introduced the idea of the ruin to China. To resolve the cultural dichotomy-the apparent contradiction between the Eastern and Western approach to the manifestation of age value-we must arrive at a broader/more abstract definition of the stimulus (catalyst). Here, it pays to borrow some premises from Wu Hong's art historical analysis that demonstrates the ability of qiu 丘 (a natural mound; a site of a ruined settlement) and $x u$ 墟 (emptiness; wasteland as in the compound word qiuxu) to evoke the lament of the past based on the notion of erasure, i.e. complete disintegration of physically tangible material and thus non-existence (Wu 2012, 18 and 27). 'By looking at (or thinking about) a ruined city, an abandoned palace, or a silent "void" left by historical erasure, one feels that one is confronting the past, both initially linked with it and hopelessly separated from it.' (Wu 2012, 18)

In other words, in the Chinese context, a mound of rubble (qiu) and even more so a vast, empty space $(x u)$ stripped of any visible traces of history's debris are the very catalysts that enable an emotional response (aesthetic experience) to the progressive cycle of life. In comparison with the West, this means that: first, historical memory becomes detached from physical substance and signs of demise (incompleteness, imperfection in the form of rust or patina) which is the key to the Eurocentric understanding of age value (and almost a quarter of a century after the Nara Document, still the basis of modern monument preservation); and second, the speed at which time elapses, evident in the stages of deterioration a monument goes through, can be accelerated, switching from existent to non-existent modes in the space of a moment, but without having to sacrifice the viewer's subjective awareness and sensitivity to the passage of time.

This can be easily achieved in the digital environment. At the touch of a button, 3D digital modelling can create an imaginary but realistic setting in a computer-generated virtual reality (Figure 6a, Figure 6b), and moreover, allows effortless changeovers between different (virtual) realities.

\section{Riegl's Ideas on Conjectural Restoration and Fear of Formlessness-Duplex Visualisation Mode/ Double Vision of Conservation and Restoration}

Riegl's claim of history's progressive development (and obedience to nature's laws) rules out the possibility of reconstruction of a monument in the real world; although he allows for the possibility of safeguarding under certain circumstances. This can be partly explained by the time in which Riegl lived. Riegl argues against $19^{\text {th }}$-century preservation practice that was still concerned with 'a reconstruction of the past as present' and 'the evocation of historical stages in their original perfection' (Zerner 1976, 186); in other words, conjectural restoration in the mode of Viollet-le-Duc. Here, restoration is not understood in the modern sense of a legal measure in preservation work as defined in the Venice Charter, which claims that 'it 
must stop at the point where conjecture begins, and in this case moreover any extra work which is indispensable must be distinct from the architectural composition and must bear a contemporary stamp' (Venice Charter 1964, Article 15).

And yet, as Naginski suggests, the modern (Western) viewer needs to visualise loss (stratigraphic picturing of material debris) as much as he wants to visually recover the supposed original state of the monument (Naginski 2001, 138). This requires a duplex mode of visualisationon the one hand, recording age value and the traces of decay, and, on the other, historical value and the original state of creation-that has a long history. An outstanding example is provided by Giovanni Battista Piranesi (1720-1778), the foremost engraver of the $18^{\text {th }}$ century, in his Prima parte di Architettura e Prospettive (1743), a series of vedutes that reveal a double vision of Rome (Pinto 2012). Eleven of the 13 plates depict architecture that is still in perfect condition and present Piranesi's emotional response to the ancient monuments rather than their authentic documentation (Wendorf 2001). Touched by age value, he enthusiastically declares: 'These speaking ruins [that served as my models] have filled my spirit with images that accurate drawings, even such as those of the immortal Palladio, could never have succeeded in conveying.' (Piranesi 1843, dedication page)

Without doubt, his restoration drawings are architectural fantasies (caprices), but they point to the conflicting modes of visual recovery. The tantalising mix of fact and fiction goes hand in hand with a lack of transparency, as the German novelist Johann Wolfgang Goethe (17491832) once sadly observed during his Italian journey: 'It must, in truth, be confessed, that it is a sad and melancholy business to prick and track out ancient Rome in new Rome.' (Goethe 1816, 201)

This is not to say that no efforts were made to separate the wheat from the chaff and distinguish between the notions of conservation and restoration (intellectual transparency). The Italian architect Carlo Fontana (1634-1714), at least a generation older than Piranesi and Goethe, captures the apparent opposites of past and present of the same monument-the Flavian Amphitheatre (L'anfiteatro Flavio) better known as the Colosseum in Rome; posthumously printed in 1725 (Pinto 2012). One print visually recovers the monument and proposes its original form during the initial construction phase (past), while another print documents the ancient building in its ruined condition in the $18^{\text {th }}$ century (present). The problematic double vision of past and present eventually developed into the fierce conservation-restoration debate of $19^{\text {th }}$-century positive historicism, culminating in the diametrically opposed ideas of Viollet-le-Duc (conjectural restoration) and John Ruskin (1819-1900) (Spurr 2007), the leading art critic of $19^{\text {th }}$-century Victorian England, who famously denounced the very concept of restoration as 'a lie from beginning to end' (Ruskin 1849, 196).

It is not surprising that Riegl appears close to Ruskin, whose Seven Lamps of Architecture had appeared in a German translation in 1900, and had led the field from a duplex mode toward a single visualisation mode, consolidating the preference for conservation (factual documentation of the past) over restoration (conjectural recreation of the past) that would later become legalised in the Venice Charter. The European adherence to material authenticity as an effective means of legitimation of a monument's past builds on the historical inability to represent the past and the present superimposed on one another or next to each other. In the light of today's knowledge, the skepticism towards restoration is quite understandable at a time when the hands of preservationists were tied and lacked effective means to visually discern original, later repair, and conjecture: in the words of Riegl, 'all human restoration and calculation is prone to individual error' (Riegl 1903, 74). It ultimately stems from a fear of conjecture and figuratively speaking, the fear of losing the past, and resulted in the valorization of the past as the one and only form of true scientific representation. Ruskin's harsh criticism of the common practice of restoration illustrates the inherent danger of destruction that might result in an irrevocable loss of information: 'Restoration, so called, is the worst manner of destruction. It means the most total destruction which a building can suffer: a destruction out of which no remnants can be gathered ... It is impossible, as impossible as to raise the dead, to restore anything that has ever been great or beautiful in architecture.' (Ruskin $1849,194)$

But the fear of the viewer goes in both directions, from over-perfection on the one hand (a newly restored monument appears as if it is new), to a sort of 'illegibility' on the other (preserved in such a state of decay that the monument is no longer recognisable). Riegl, in fact, was aware of the fear of formlessness, as summarised by Naginski: 'The ruin's visual impact increases as decay becomes more apparent; it seems clear that the wall photograph and the stratigraphic regime it deploys repeatedly mimicked that effect. The effect has limits: when nothing is left but a shapeless pile of rubble, the monument becomes formless-reduced to illegibility, nothingness and death.' 

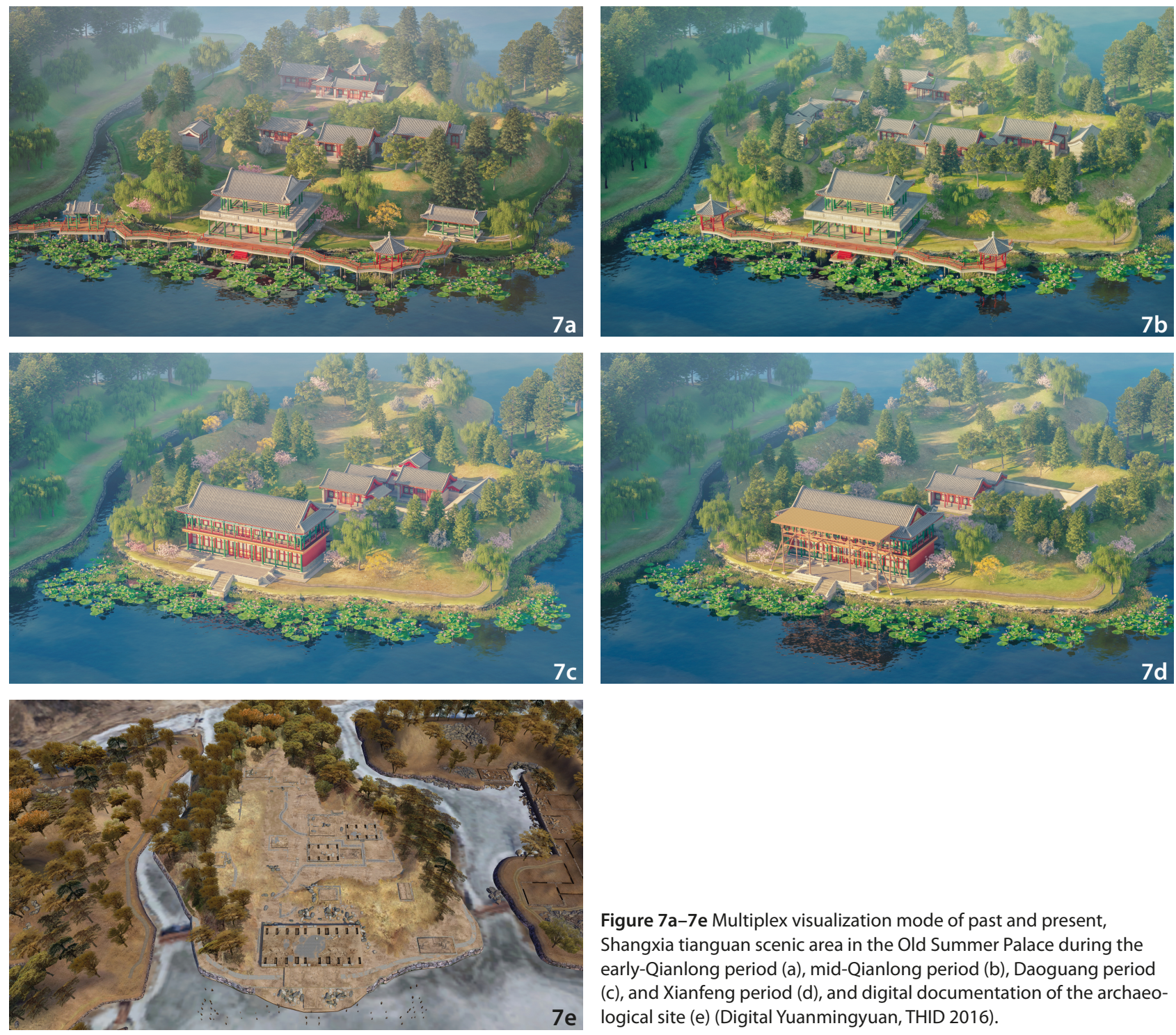

Figure 7a-7e Multiplex visualization mode of past and present, Shangxia tianguan scenic area in the Old Summer Palace during the early-Qianlong period (a), mid-Qianlong period (b), Daoguang period (c), and Xianfeng period (d), and digital documentation of the archaeological site (e) (Digital Yuanmingyuan, THID 2016).

(Naginski 2001, 152)

Today, 3D digital modelling and virtual reality can finally settle the old problem of conflicting modes of representation by providing visualisation strategies that simultaneously show the past and the present (Figure 7). Modern information technologies can cover the whole spectrum of conditions from incompleteness to perfection and illustrate a monument in its (dilapidated) condition at any particular period in time and also in its original state. Today it is possible to capture the complexities of such data and explore overlapping layers without destroying any of them (i.e., not causing material damage, and with no physical intervention).

As important, age value introduces a sense of distance that serves to position the viewer in the larger framework of history, allowing connection with it but at the same time separation from the past. In the digital environment,

augmented reality (AR) can achieve this historical distance, and act like a slider control that the viewer can use at any time to regulate his relation to the monument (remote or close). In contrast to virtual reality, it does not replace the real physical world with a simulated reality like the world but rather supplements the live direct view of the physical environment with computer-generated graphics.

\section{Conclusions}

The $21^{\text {st }}$ century poses new challenges to the traditionally conservative and protective field of monument preservation, but an encounter between history and cutting edge technologies opens up new possibilities for viewing the past. In fact, the Venice Charter demands that new sciences and innovative techniques be embraced, for the 
study and safeguarding of architectural heritage (ICOMOS 1964, Article 1).

For more than 100 years, Riegl's value system, the basis of the Venice Charter, has been the benchmark in monument preservation at national and international levels and, as suggested in this paper, it is still the standard by which innovations in the field should be measured. The main obstacle in exploring digitisation as a driving force in monument preservation today remains a restrictive thinking that stems from the Western emphasis on material substance and authentic material.

And yet, to Riegl, the historicity of artefacts builds on the changing perception of the monument over the centuries, whereby its commemorative value increases with each consecutive development stage, which, in turn, embraces the previous one (progressing from deliberate commemorative value and historical value to age value). Inspired by Riegl (reality is perceived through feelings, not rationalised through intellect), we might take the next step and spin his progressive theory further. But what is the next step in monument perception, or let me phrase the question differently and ask: how does the application of digital techniques change our perception of the monument? The answer is surprisingly simple. If we (allow ourselves to) break down the boundaries between time and space in real time, we can equate physical reality and virtual reality and accept $3 \mathrm{D}$ digital models of physical monuments as being exact replicas, with the same importance as the original, rather than just pale imitations. And then simulation, (full-body) immersion and interaction between real and imaginary worlds become means for visualising the past (Heim 1993).

Thus, we can draw the following conclusions:

First, generally speaking, modern information technologies can accomplish the same results, and just as well, as traditional means of monument preservation (ranging from paper-based drawings and photographs to nondestructive safeguarding and restorative measures) and likewise, implement the supreme preservation principle today-to conserve (to keep), as a means of protecting a historic monument and its urban or rural setting that has 'acquired cultural significance with the passing of time' (ICOMOS 1964, Article 1), in line with the Venice Charter. Moreover, modern information technologies do so virtually, in a non-destructive, non-invasive way, without material intervention that would endanger the physical substance of a monument.

Second, and more specifically, modern information technologies can express Riegl's commemorative values.
To start with, realistic 3D models can evoke feelings, the principal aim of age value, not least because the viewer identifies with the digital mode by virtue of the high level of clarity, excellent graphic qualities, and attractiveness and memorability of form. Additionally, digital models can, as historical value requires, capture the condition of a site at a specific moment in time and preserve it for future generations-producing a digital historical 'document' in the form of a spatial reconstruction model that is not subject to further decay in the real world. And finally, digital modelling lends itself to restoration of the (supposed) original form or structure of a monument-adding the missing features while removing features from other periods in its history that were attached during later restoration-and thus serve as a memorial in accordance with the concept of deliberate commemorative value.

Third, modern information technologies can surpass traditional monument preservation by settling the old century-long conflicts among Riegl's past and present values. The most serious of these conflicts is the dichotomy between age value and historical value, that reveals itself not only in their different perceptions (immediate emotional response by the uneducated masses versus in-depth/ lengthy rational study by only a small group of learned art historians) but even more so in their diametrically-opposed goals-glorifying the progression of decay versus stopping it. Next, age value competes with newness value for attraction value to the masses and in appreciation for its own sake-the old being valued for its age and decay (nostalgia cult); the new for its newness and completeness (youth cult) - and their divergences were widening to the point at which $19^{\text {th }}$-century interpretive restoration (newness value) became incompatible with Ruskin's and Riegl's conservation policy of non-intervention (age value). Last, the fundamental requirement of deliberate commemorative value is also restoration, although on a more moderate level, and in a more gentle way but still, it violates the natural ageing process crucial to age value. Riegl reluctantly admitted that his time was still a period of transition and internal battle of competing values, and it is only more than 100 years later, that we successfully completed the changeover. Today, digital modelling and virtual reality allow the mapping of historical information through time and the visualisation of the epochal change of a site in a duplex (or even multiplex) mode, by simultaneously viewing the conservation (age; disintegrated form) and the restoration (newness; unbroken complete form) of the same object. In practice, in the case of a complex cultural heritage landscape, each scenic area that experienced the 


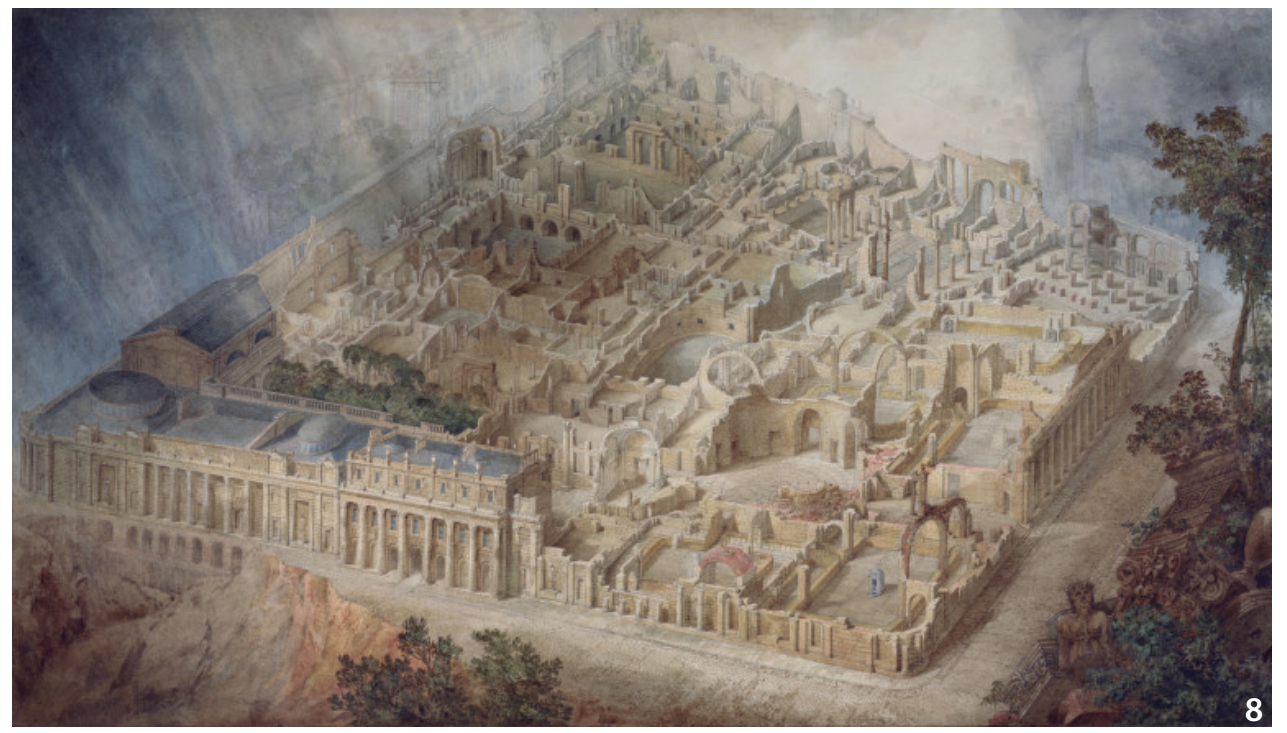

Figure 8 Joseph M. Gandy (1771-1843), A bird's-eye view of the Bank of England, 1830 (With courtesy of the Sir John Soane's Museum London).

vicissitudes of history in different ways is divided into tempo-spatial units that are individually captured in digital models and superimposed on another afterwards.

Fourth, modern information technologies can exceed our expectations through their ability to go beyond the boundaries of time and embrace it in two directions-not only to go backwards (the past) but also to go forwards (the future) in it. In purely hypothetical terms, I would suggest that it is possible to follow a three-fold concept of past-present-future that exploits the potential of digitisation and virtual reality to visualise the passage of time in the information age-not only restoring buildings to their original state but also predicting their slow decay at any given time in a future urban and rural context (risk management; loss scenario). A pioneering example, albeit in the traditional context, is provided by Joseph M. Gandy's (1771-1843) visionary painting of John Soane's (17531837) Bank of England in ruins (1830): it shows the newly rebuilt structure in dramatic luminous perspective as if it were a Roman ruin and predicts the deterioration process at an imaginary point of time in the future (Figure 8) (Lukacher 2006).

Fifth, virtual reality resolves the (Western viewer's) fear of formlessness through its imaginary setting in an illusory world where boundaries between modes of existence (physically tangible) and non-existence (already lost or disintegrated) become blurred or even disappear. A monument degraded beyond recognition and stripped of any distinct trace of form is to Riegl nothing more than 'a dead, formless fragment of the immensity of nature's force' and cannot convey age value (Riegl 1903, 74). But here Riegl might have been wrong, or at least too concentrated on European traditions. Such 'a bare, shapeless pile of stones' can regain form and thus, return to consciousness and life in no time, because in the digital environment it appears once again in front of our eyes at the touch of a button. What is more, this gains additional cultural significance: by doing so, modern information technologies can strike a balance between the European belief in material authenticity and the Asian notion of erasure that values the void as a stimulus for the aesthetic experience with which to confront the past (age value).

\section{Notes}

1. For the history of this publication see Bacher 1995, Scarrocchia 1995, Arjones Fernández 2007. For an English translation of the German texts see Bruckner and Williams 1996, or alternatively, Kurt Forster and Diane Ghirardo 1998 (In Oppositions: Selected Readings from a Journal of Ideas and Criticism in Architecture 19731984, edited by Michael Hays: 621-653. Princeton: Princeton Architectural Press).

2. Together with his colleague at Vienna University, the Austrian art historian Franz Wickhoff (1853-1909), Riegl played a seminal role in the early Vienna School of Art History (Wiener Schule der Kunstgeschichte) that had considerable impact on art historians of succeeding generations.

\section{References}

Arjones Fernández, Aurora. 2007. Alois Riegl: El Culto Moderno de los Monumentos, su Carácter y sus Orígenes. Sevilla: Instituto Andaluz del Patrimonio Histórico. Bacher, Ernst. ed. 1995. Kunstwerk oder 
Denkmal? Alois Riegls Schriften zur Denkmalpflege. Vienna: Böhlau.

Brodey, Sigrun. 2008. Ruined by Design: Shaping Novels and Gardens in the Culture of Sensibility. New York: Routledge.

Falser, Michael. 2005. "Zum 100. Todesjahr von Alois Riegl." Österreichische Zeitschrift für Kunst- und Denkmalpflege 59 (3/4): 298-311.

Falser, Michael, Wilfried Lipp, and Andrzej Tomaszewski. eds. 2010. Conservation and Preservation: Interactions between Theory and Practice-In Memoriam Alois Riegl (1858-1905). Firenze: Polistampa.

Goethe, Johann Wolfgang. 1816. "Italienische Reise.” Translated by A. J. Morrison. New England Review 33 (1): 199-202.

Gubser, Michael. 2005. “Time and History in Alois Riegl's Theory of Perception." Journal of the History of Ideas 66 (3): 451-474.

Harris, Eduard et al., eds. 1993. Practices of Archaeological Stratigraphy. San Diego: Academic Press.

Heim, Michael. 1993. The Metaphysics of Virtual Reality. Oxford: Oxford University Press.

International Council on Monuments and Sites (ICOMOS). 1994. The Nara Document on Authenticity on Authenticity. Nara, Japan. Accessed April 1 2017. www. icomos.org/charters/nara-e.pdf

Lamprakos, Michele. 2014. "Riegl's 'Modern Cult of Monuments' and The Problem of Value." Change Over Time 4 (2): 418-435.

Lehne, Andreas. 2010. “Georg Dehio, Alois Riegl, Max Dvorak-A Threshold in Theory Development." In Conservation and Preservation: Interactions between Theory and Practice-In Memoriam Alois Riegl (18581905), edited by Michael Falser et al.: 69-81. Firenze: Polistampa.

Lukacher, Brian. 2006. Joseph Gandy: An Architectural Visionary in Georgian England. London: Thames \& Hudson.

Naginski, Erika. 2001. "Riegl, Archaeology, and the Periodization of Culture." Anthropology and Aesthetics 40: 135-152.

Olin, Margaret. 1985. “The Cult of Monuments as a State Religion in Late $19^{\text {th }}$-century Austria." Wiener Jahrbuch für Kunstgeschichte 38: 177-198.

Petzet, Michael. 2004. "Principles of Conservation: An Introduction to the International Charters for Conservation and Restoration 40 years after the Venice Charter." Monuments and Sites 1: 7-29.

Pinto, John. 2012. Speaking Ruins: Piranesi, Architects and
Antiquity in $18^{\text {th }}$ Century Rome. Ann Arbor: University of Michigan Press.

Riegl, Alois. 1893. Stilfragen: Grundlegungen zu einer Geschichte der Ornamentik. Berlin: George Siemens.

Riegl, Alois. 1992. Problems of Style: Foundations for a History of Ornament. Translated by Evelyn Kain. Princeton: Princeton University Press.

Riegl, Alois. 1903. Der moderne Denkmalkultus: Sein Wesen und seine Entstehung. Vienna: Braumüller.

Riegl, Alois. 1996. “The Modern Cult of Monuments: Its Essence and Its Development." Translated by Karin Bruckner and Karen Williams. In Historical and Philosophical Issues in the Conservation of Cultural Heritage, edited by Nicholas Stanley-Price et al.: 69-83. Los Angeles: Getty Conservation Institute.

Ruskin, John. 1849. Seven Lamps of Architecture. London: Smith, Elder \& Co. Reprint 1989. New York: Dover.

Scarrocchia, Sandro, ed. 1995. Alois Riegl: Teoria e Prassi della Conservazione dei Monumenti: Antologia di Scritti, Discorsi, Rapporti 1898-1905. Bologna: Clueb.

Spurr, David. 2007. "Ruskin and Viollet-le-Duc: Figures of Ruin and Restoration." Chora 5: 285-308.

Congress of Architects and Technicians of Historic Monuments. 1964. The International Charter for the Conservation and Restoration of Monuments and Sites (The Venice Charter). Venice, Italy. Adopted by ICOMOS in 1965. Accessed April 1 2017. http://www.icomos.org/ charters/venice_e.pdf

Wendort, Richard. 2001. "Piranesi’s Double Ruin.” Eighteenth-Century Studies 34 (2): 161-180.

Wood, Christopher, ed. 2000. The Vienna School Reader: Politics and Art Historical Method in the 1930s. New York: Zone Books.

Wu Hong. 2012. A Story of Ruins: Presence and Absence in Chinese Art and Visual Culture. London: Reaktion.

Zerner, Henri. 1976. "Alois Riegl: Art, Value, and Historicism." Daedalus 105 (1): 177-188. 